\title{
Research on Application-oriented Talent Training Mode Based on the Perspective of School-enterprise Alliance
}

\author{
Yanchao Liu* \\ Liaoning Institute of Science and Technology \\ Benxi, China \\ *Corresponding author: liu_yanchao@foxmail.com
}

\begin{abstract}
Training innovative and application-oriented talents that are in line with social needs is the primary task of universities, and it is also beneficial to the rapid development of China's economy. University-enterprise cooperation is an effective way of cultivating applied talents. Taking the public elementary computer courses in universities as examples, this paper expounds the present situation of public elementary computer courses in colleges and universities and the significance of reforming the application-oriented talents training mode, as well as the teaching reform carried out in the ways of the joint development between higher vocational colleges and curriculum resources, online and offline teaching, creation of the multidimensional stereoscopic practice teaching platform.
\end{abstract}

Keywords-school-enterprise alliance; application-oriented talents; training mode

\section{INTRODUCTION}

At the third plenary session of the 18th Communist Party of China (CPC) central committee, The Decision of the CPC Central Committee to Comprehensively Deepen the Reform on Several Major Issues pointed out that "it is essential to accelerate the construction of modern vocational education system, deepen the integration of industry and education and school-enterprise cooperation, and train high-quality workers and skilled personnel.” Premier Li Keqiang also pointed out that "the structure, quality and level of the education supply cannot fully adjust itself to the industrial demand for talents in China”. In 2017, General Secretary Xi Jinping pointed out in the report of the 19th national congress of CPC that "we will improve vocational education and training systems, deepen integration between industry and education and cooperation between schools and enterprises, accelerate the construction of first-class universities and disciplines, and achieve the connotative development of higher education.”

Under this background, strengthening school-enterprise cooperation is a vital method to educate creative and applied talented persons in the new era[1]. Focusing on the perspective of the university-enterprise alliance, this paper takes the public elementary computer courses in colleges and universities as an example to discuss the construction of application-oriented talent training mode, which is of great significance and value.

2019, BenXi Provincial Federation Social Science Circles project” Research and Practice of Applied Talents Training Model Based on SchoolEnterprise Alliance”

\section{The PRESENT Situation OF Public Elementary COURSES IN COLLEGES AND UNIVERSITIES}

At present, universities offer a number of public compulsory courses for non-computer majors, mainly including C Language Programming, Visual Basic Programming and Visual FoxPro Programming. The language of these programming is characterized by simple grammar and powerful functions. Compared with another professional computer programming, they are easier to learn, to use and to debug. The main teaching purpose of these courses is to enable students to start from simple problems, to design problemsolving algorithms, to write program codes and to solve practical problems, so as to improve the application ability of computers of college students and cultivate their innovative thinking, consciousness and spirit.

According to the requirements of the Ministry of Education on computer technology for non-computer majors, it is the primary task to cultivate students' ability to analyze and solve problems by computer. Most colleges and universities offer compulsory computer programming courses in their freshman year, but the learning time of the courses is relatively short in the process of teaching, and students lack the initiative to connect the courses with other professional courses. Therefore, there are quite a few students who only master basic grammar knowledge and the use of basic controls after learning this course. In particular, they lack the ability to analyze and solve problems and the awareness to apply the learning content of this course to their future professional work.

III. SigNifiCANCE OF APPLICATION-ORIENTED EDUCATION MOdE FOR TALENTS FROM THE PERSPECTIVE OF SCHOOL AND ENTERPRISE ALLIANCE

Recently, the strategy of the development of applicationoriented talent training mode has become a major trend in developing universities. Attaching importance to practical teaching and strengthening the cultivation of applicationoriented talents are important ways to improve students' professional quality and employment competitiveness[2]. How to improve the ability of computer application of college students is also a problem that every university has to face. It is essential to integrate industry and education, rely on enterprise resources, take the reform of college public elementary 
computer courses as the research content, improve college students' computer application ability and take computer knowledge as the professional service application ability as the goal, and lay a foundation for the training of applied talents[3]. It is necessary and significant to implement the applicationoriented talent training mode, which is summarized as follows:

1) Provide high-level applied talents for employers. As the subjects covered in universities are extensive and complicated, and to some extent, there is a phenomenon of interdisciplinary with rich teaching resources. Therefore, by adopting the mode of integrating industry and education, colleges and enterprises can effectively connect and adjust the mode of applicationoriented personnel training based on the needs of enterprises for talents, which can help to avoid the contradiction between the posts of enterprises and talents of universities, thus avoiding the disconnection between application-oriented talents of colleges and universities and the society [4].

2) Provide some references for universities to construct training system for talented personnel. As we all know, teaching recourses in universities are derived from different fields in modern society. Universities, on the basis of the actual needs of enterprises for talents, achieve in-depth communication and docking with enterprises, which can provide certain references for colleges and universities to develop application-oriented talent training system.

3) It can deal with the employment issues of applicationoriented talents in universities with effectiveness. Universities and enterprises can give full play to their respective advantages and realize deep docking based on the demand of profit distribution of both sides, which is conducive to solving the employment problem of application-oriented talents in universities and improving the employment rate of graduates. It can be said that this has become an employment channel for application-oriented talents in universities[5].

4) It is conducive to national economic development. Science and technology are national weapons. Every modern power in the world is strong in innovation and science and technology. Accelerating the construction of an innovationoriented country is the inherent requirement for China to become a powerful modern country. The innovation in the field of science and technology needs to rely on the innovation of talented personnel, and the education of creative and applied talented personnel is the top priority, which raises new requirements for colleges and universities in educating talents. Universities at home and abroad pay a lot of attention to the cooperation of school-enterprise alliance and have cooperated with enterprises to varying degrees. The practice has proved that schools and enterprises can improve students' innovation ability and promote the development of national experience through joint cultivation, mutual support, mutual penetration, two-way intervention, complementary advantages and mutual use of resources.

\section{PLAN OF TEACHING REFORM}

A. Integrating industry and education, and jointly develop curriculum resources by schools and enterprises.

The project vertically integrates the resources of schools, enterprises and society in the process of cultivating innovative talents, introduces industry projects and work experience into professional education, and vertically integrates the needs of industry and education. The government, enterprises, research institutions and universities are vertically arranged across the system; In-class practice, curriculum design, innovative projects and enterprise projects are vertically integrated[6].

Build an environment for the growth of industrial talents, including industry-level working environment (construction of experimental software and hardware environment, project teaching and management, etc.), build a practical platform, set up a school-enterprise mixed technical team, build a practical operation mode of "basis + personalization + team", and complete enterprise-level project research and development. By participating in these projects, we, as students, are able to make use of the knowledge that is learned from class in combination with real projects of enterprises[7].

\section{B. Carrying out online and offline teaching to expand students' learning space}

Build an online teaching platform. Through organically combining online and offline teaching, teachers can simply and intuitively arrange courses and effectively implement teaching with the help of the teaching platform. Online platforms give full play to the role of the Internet and mobile terminals, breaking the limitations of teaching space and time and helping teachers fully mobilize and allocate various resources. The combination of online and offline activities enables teachers and students to carry out activities in linear flow "classroom". Discussion, interaction, sharing and evaluation based on the courses can happen anytime and anywhere naturally, which greatly improves the depth and width of the course.

\section{Creating a multi-dimensional practical teaching platform to cultivate students' innovative ability}

Based on the teaching practice platform, supported by innovative practice platform and extended by vocational training platform, this platform is oriented to job requirements and engineering projects. With the training of students' innovative capacity as the center, the teaching methods such as case teaching, scenario simulation, practical training, entrepreneurial practice and so on are fully integrated[8,9]. The design of the platform is as shown in Fig. 1.

Teachers can reform teaching methods in class and adopt multi-roles, multi-places and multi-types of practices after class to ensure the smooth implementation of the practice teaching system and lay a foundation for the cultivation of applicationoriented talents[10]. 


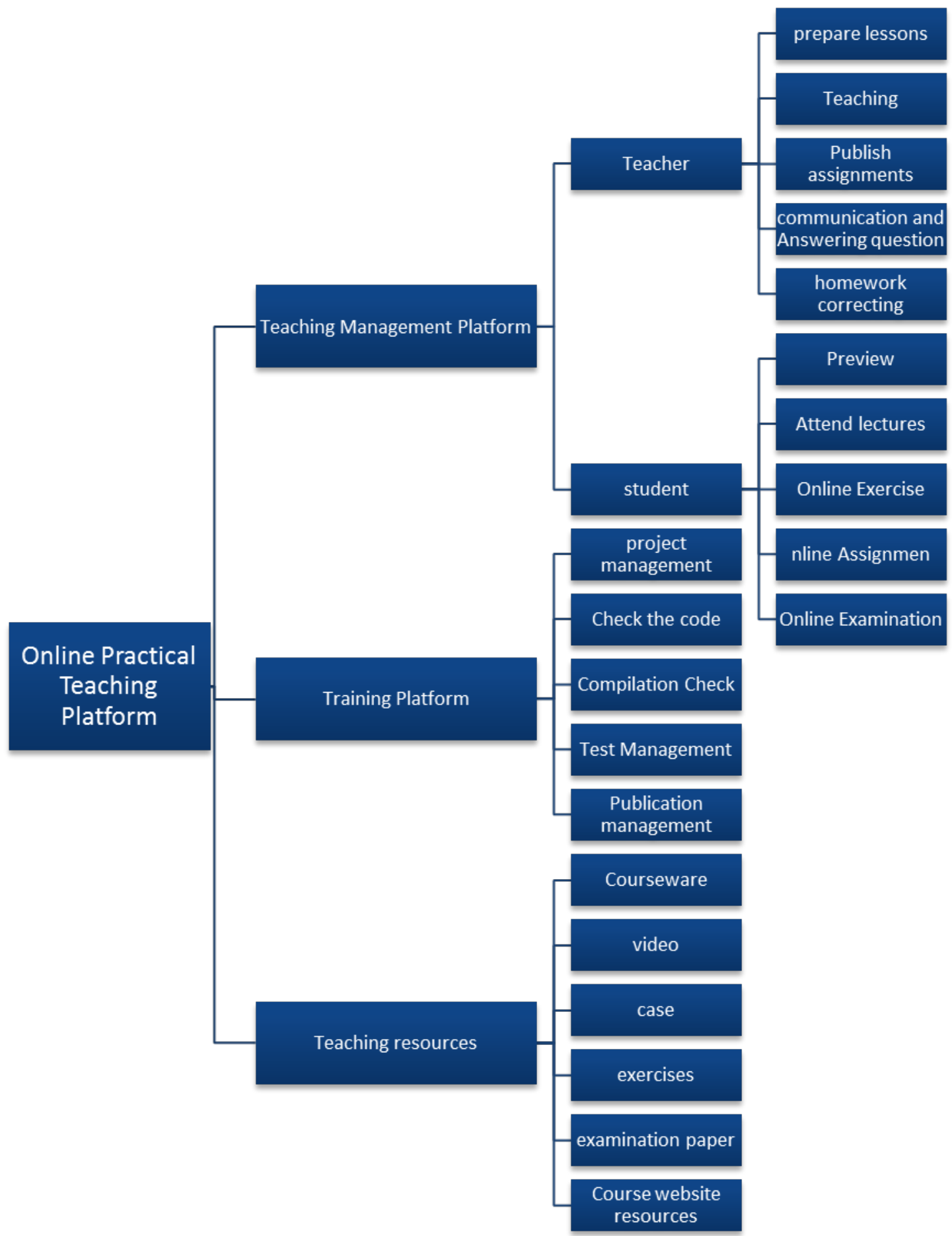

\section{CONCLUSION}

With the continuous development of society and economy, there is a higher demand for talents, so new challenges have been put forward for the talent training mode in colleges and universities. School-enterprise alliance and integration of industry and education are important ways to cultivate innovative and applied talents in the new era. This paper puts forward the significance and ideas of the reform of applicationoriented education mode for talented personnel from the perspective of school and enterprise's alliance, taking the basic public computer courses as an example. Through school and enterprise's collaboration, the resources of schools and enterprises can be shared, and the targeted training of application-oriented talents can promote the organic integration of educational business and economy, educate creative and application-oriented talented persons that can adapt to rapid economic development, and reach win-win result among schools, enterprises and society. 


\section{REFERENCES}

1] Y.X. Wu, C.W. Wang. "Innovative and Applied Talents Training Model Based on Professional School-Enterprise Cooperative Alliance. "University Teaching in China, 2012(9)pp.75-77.(In Chinese)

[2] B. Yu. "A Model for Training Application-Oriented Talents of Computer Science of Independent College." Second International Workshop on Education Technology \& Computer Science IEEE, 2010.

[3] H.C. Xu, et al." Investigation on the Training Mode of the ComputerApplication Talents Based on the Information-Technology Orientation." Communications in Computer \& Information Science 202(2011):487492.

[4] Y. Niu, H. Xia, Y. Zhang, et al. "Study on Training of ODC Talents through School-Enterprise Cooperation.” Third International Conference on Digital Manufacturing \& Automation. IEEE Computer Society, 2012.

[5] N. Luo.” Research on the Training Model of Applied Talents of Computer Major in Colleges and Universities Based on Collaborative Innovation between Schools and Enterprises.” Digital World, Tianjin, 2017(3) pp.422-423. (In Chinese)
[6] X.J. Ding. "Training high vocational talents with school-enterprise cooperation: A case study", International Conference on Information Science \& Engineering. IEEE, 2011.

[7] J.J. Qi, H.W. Xu. "Research and Practice on the Training Mode of School-Enterprise Cooperative Talents for Computer Major.” Financial Theory and Teaching, Harbin,2016(2)pp.63-65.(In Chinese)

[8] Y.C. Liu.” Design and Development of Computer Assembly Virtual Simulation Platform Based on Vocational Education. "2017 3rd IEEE International Conference on Computer and Communications (ICCC), 2017, pp.2474-2478.

[9] Y.C. Liu. "Application of the Computer Assembly Virtual Platform in Higher Vocational Education.” 3rd International Seminar on Education Innovation and Economic Management(seiem),2018,pp.545-548

[10] J. Huo. "Reform and Practice of Training Mode of Applied Talents Based on School-Enterprise Cooperation. "Educational and Teaching Forum, Shijiazhuang, 2014(44)pp.41-43. (In Chinese) 